\title{
Development of Non-Shrinking Soft Ferrite Composition Useful for Microinductors Applications
}

\author{
Narla Varalaxmi ${ }^{1,2}$, Kota Sivakumar ${ }^{2}$ \\ ${ }^{1}$ Department of Physics, Kakatiya University, Warangal, India; ${ }^{2}$ Ceramic Composite Materials Laboratory, Department of Physics, \\ Sri Krishnadevaraya University, Anantapur, India. \\ Email: laxmisharmanarla@gmail.com
}

Received March 14 ${ }^{\text {th }}, 2011$; revised June $16^{\text {th }}, 2011$; accepted June $25^{\text {th }}, 2011$.

\begin{abstract}
NiCuZn Ferrites are widely employed for many electronic applications, but can be replaced by MgCuZn ferrites owing to their superior properties like high initial permeability, high resistivity, low magnetostriction, environmental stability and low cost. Three series of NiMgCuZn ferrites were prepared by conventional sintering process. The formation of single phase in these ferrites was confirmed by X-ray diffraction. Initial permeability measurements on these samples were carried out in the temperature range of $30^{\circ} \mathrm{C}-400^{\circ} \mathrm{C}$. The effect of the external applied stress on the open magnetic circuit type coil with these ferrites was studied by applying uniaxial compressive stress parallel to magnetizing direction and the change in the inductance was measured. The variation of ratio of inductance $(\Delta L / L) \%$ increases upto certain applied compressive stress and there after it decreases, showing different stress sensitivities for different compositions of ferrites studied in the present work. With a view to develop stress insensitive NiMgCuZn ferrite, a low stress sensitivity composition among all the ferrites studied was chosen and different amounts of $\mathrm{SiO}_{2}$ were added to it and a series of ferrite compositions were prepared. The variation of ratio of inductance $(\Delta L / L) \%$ with external applied compressive stress was examined. These results show that, in a particular composition of $0.05 w \% \mathrm{SiO}_{2}$ added $\mathrm{Ni}_{0.3} \mathrm{Mg}_{0.3} \mathrm{Cu}_{0.1} \mathrm{Zn}_{0.3} \mathrm{Fe}_{2} \mathrm{O}_{4}$ ferrite exhibited stress insensitivity. It was noticed that addition of $\mathrm{SiO}_{2}$ was found to be effective in reducing the stress sensitivity. This was confirmed from the elastic behaviour studies at room temperature on these ferrite samples. These studies were carried out to develop a ferrite composition for its use as core material for microinductor applications.
\end{abstract}

Keywords: X-ray diffraction, Ferrite composites, Initial permeability, Microinductors, Stress Insensitivity, SEM photographs

\section{Introduction}

Microminiaturization of electronic circuits especially in the fields of mobile communication and information technology demands electronic components with very small size [1]. Recently, the surface mounting devices (SMD) such as microinductors and multilayer chip inductors have been rapidly developing for electronic applications. NiCuZn ferrites and $\mathrm{MgCuZn}$ ferrites are suitable for micro inductor applications. They find applications in the latest electronic products such as cellular phones, video cameras, note book computers, etc., and they require miniaturization. Recent technological developments concerning electrical devices demand higher performance of the inductor i.e. higher frequency application and further miniaturization. To satisfy these demands, NiCuZn ferrite [2-16] is best suited ferrite for these applications as Surface Mounting Device (SMDs). There are two types of SMD's, multilayer chip and the wound chip inductors. Dram-type core is wire bound and moulded to resin, in order to stand up against mechanical shocks and moisture. During hardening, the resin shrinks and applies compressive stress to the core, which influences material behaviour. The shrinkage produces heavy stress on the core material and the inductance decreases $[17,18]$. This decrease in inductance results in much lower values of the moulded inductors and it will be a problem in mass production.

The initial permeability of a ferrite is very sensitive 
property to the external stress. Generally an external compressive stress around $1000 \mathrm{~kg} / \mathrm{cm}^{2}$ is produced on the core during hardening of the resin [18]. This results in decreased values of inductance. This posses a big problem for highly inductive $\mathrm{NiCuZn}$ ferrites in mass production. Oshaia [17] reported that it is well known that $\mathrm{PbO}$ addition to the ferrite eliminates this inductance change. However, from an environmental point of view, lowering the amount of poisonous additive is desirable and thus tried to develop less- poisonous stress insensitive NiCuZn ferrite. The mechanism of stress insensitivity was proposed by Kumagi of TDK, Japan [18]. According to him, internal tensile stress inside the grains resulting from a difference in thermal expansion coefficients, causes in stress sensitivity, when a grain boundary phase occurs with a thermal expansion coefficient larger than that of the grains, tensile stress are produced inside the grains under cooling conditions. Such tensile stress cancels external compressive stress to some degree. Thus, the cancellation of compressive stress shifts the stress sensitivity curve. Further more, not all compressive stress applies to the grains directly. Grain boundary phase divides external compressive stress, thus broadening stress sensitivity. Thus, preconditions for stress insensitivity are considered to be:

1) Applying tensile stress to the grains;

2) Absorbing the external stress applied to the grains.

To apply tensile stress to the grains, additives with a small thermal expansion coefficient is necessary. In addition, so as to apply the stress effectively, the additives needs must wet the matrix well and he tried three different oxides that have low melting points, $\mathrm{PbO}, \mathrm{Bi}_{2} \mathrm{O}_{3}$ and $\mathrm{V}_{2} \mathrm{O}_{5}$ etc., as additives. From, the environmental point view, $\mathrm{Bi}_{2} \mathrm{O}_{3}$ is the best additive among the three additives and tried to improve the stress insensitivity by adding $\mathrm{Bi}_{2} \mathrm{O}_{3}$. After many examinations he found that the combined addition of $\mathrm{Bi}_{2} \mathrm{O}_{3}, \mathrm{SiO}_{2}$ and $\mathrm{MgO}$ was the additive complex which gives best result. Probably, the reason for this improvement is that the external stress was absorbed by rigid elements $\mathrm{SiO}_{2}$ and $\mathrm{MgO}$. Furthermore, complex addition not only improves stress insensitivity, but it also improves flat temperature dependence of inductance which is very important for inductors. In view of this in this laboratory the stress sensitivity of a series of $\mathrm{NiCuZn}$ ferrites for their use as micro-inductor core materials was studied and achieved the stress insensitivity in those ferrites [19] and could produce stress insensitivity by adding suitable additives.

It was reported that electromagnetic properties of the multilayer chip ferrite components [9,18,20-22] are influenced by the internal stresses and the diffusion of $\mathrm{Ag}$ buried in ferrite [23-30]. As the magnetostriction of
$\mathrm{MgCuZn}$ ferrites is lower than that of NiCuZn ferrites, it was expected that the multilayer chip inductor using $\mathrm{MgCuZn}$ ferrite [31] would show higher magnetic properties than that using NiCuZn ferrite. Therefore $\mathrm{MgCuZn}$ ferrites with the low sintering temperature have been developed as the materials for the multilayer chip ferrite components. Under a compressive stress, the change in permeability of low temperature sintered $\mathrm{MgCuZn}$ ferrite was lower than that of low temperature sintered NiCuZn ferrite. Moreover, one might expect that the multilayer chip inductor using low temperature sintered $\mathrm{MgCuZn}$ ferrite would show a higher inductance than the chip using low temperature sintered NiCuZn ferrite. It is thought that low temperature sintered $\mathrm{MgCuZn}$ ferrite have high potentialities.

$\mathrm{MgCuZn}$ ferrite is also a pertinent magnetic material for wide range of applications owing to its superior properties at high frequency, high resistivity, low magnetostriction, fairly high Curie temperature, environmental stability and low cost [27-34]. It is believed that the increase of permeability can be achieved by decreasing the magnetostriction constant. In view of this, in the present investigation three series of NiMgCuZn ferrite and temperature variation of initial permeability and stress sensitivity of inductance were studied.

\section{Brief Review of the Experimental Work Carried out on the Stress Sensitivity}

Stress sensitivity of inductance in NiCuZn ferrites was carried out by Ramamanohar Reddy et al., [19] and observed that stress sensitivity is more in the case of iron rich and stoichiometric iron samples while in the case of iron deficient samples the stress sensitivity was found to be less. The stress sensitivity in Ni-Mn, Ni-Mn-Co and $\mathrm{Ni}-\mathrm{Mn}-\mathrm{Co}-\mathrm{Cu}$ ferrites was studied by Kaczkowski [35] and concluded that the high stress sensitivity was observed for the ferrites with the smallest magnetocrystalline anisotropy.

The effects of chemical composition and micro structure on stress sensitivity of magnetic properties with applied stress in Ni-Mg-Cu-Zn ferrite materials were investigated, by Kanada et al., [36] and reported that on application of stress sensitivity was reduced.

Effects of stress and on microstructure in $\mathrm{Mn}-\mathrm{Zn}$ ferrite for power applications were carried out by Bienkowski et al., [37]. Manganese substituted cobalt ferrite magnetostrictive materials for magnetic sensor applications were carried out by Paulsen et al., [38]. Mechanical and electrical properties of $\mathrm{Ni}_{0.65} \mathrm{Zn}_{0.35} \mathrm{Cu}_{x} \mathrm{Fe}_{2-x}$ $\mathrm{O}_{4}$ ferrites were carried out by Abd.El-Ati and Tawfik [39]. The dependence of the rectangular hysteresis loop on the external stress in manganese-magnesium and 
manganese ferrites were reported by Czecnoslovak [40]. Jong [41] studied the control of stress sensitivity in gadolinium Yttrium iron garnets.

Enokidoy et al., [42] have studied the effects of additives on the stress and temperature dependence of in inductance NiCuZn ferrite.

Effect of glass addition and quenching on the relation between inductance and external compressive stress in $\mathrm{Ni}-\mathrm{Cu}-\mathrm{Zn}$ ferrites-glass composites were reported by Yamaguchi and Shingawa [43] and the effect of quenching temperature on the stress-inductance characteristic is discussed in terms of the bending strength and fracture mode of the composites, creep and micro crack formation during quenching are proposed to be responsible factors. Meharabi and Mintz [44] studied the influence of tempering on impact behaviour of quenched and tempered steels with low hardenability. Evaluations of mechanical properties of magnetic materials using non-destructive method were carried out by Yang et al., [45].

Vaughn et al. [46,47] studied ferrite phase shifters using stress-insensitive garnet materials.

Developments of stress-insensitive ferrite were carried out by Ikeda and Kumagi [48] and concluded that the sensitivity of the magnetic property to the external stress in $\mathrm{NiCuZn}$ ferrite was examined from the relationship between stress and permeability. In the production process of inductors, external stress is applied to the $\mathrm{NiCuZn}$ ferrite core by molding the resin, which is a protection against humidity or shock. As the permeability of $\mathrm{NiCu}-$ $\mathrm{Zn}$ ferrites are very sensitive against the external stress, the inductance of inductors changes very easily by the applied stress. This change has been recognized as the barrier to produce the inductors with a narrow inductance tolerance and found the best way to control the stresssensitivity of permeability in NiCuZn ferrite by the addition of oxide such as $\mathrm{SiO}_{2}$, and the inductance change can be completely explained from the residual stress caused by the difference of coefficients of linear thermal expansion between spinel phase (magnetic) and second phase (non-magnetic). By this process, they succeeded in developing "stress-insensitive ferrite" and the mass production of the inductors with a narrow inductance tolerance.

Nakano et al. [49] studied the development of low temperature fired $\mathrm{NiCuZn}$ ferrites and studied the high performance multilayer chip inductors and concluded that the controlling stress by the internal Ag-conductor and $\mathrm{CuO}_{1-x} / \mathrm{Ag}$ on ferrites grain boundary is most important key point for high performance multilayer chip ferrites as well as the chemical composition of ferrite. The stress insensitive ferrite for micro inductors was carried out by Kumagi and Ikeda [50].

Nakano et al., [51] have studied the magnetic proper- ties of Mg-Cu-Zn ferrites under stress were investigated and compared with $\mathrm{Ni}-\mathrm{Cu}-\mathrm{Zn}$ ferrite under a compressive stress. They observed that the change in permeability with stress of low temperature sintered $\mathrm{MgCuZn}$ ferrite was lower than that of low temperature sintered $\mathrm{NiCuZn}$ ferrite. They have also shown that the multilayer chip inductor using low temperature sintered $\mathrm{MgCuZn}$ ferrite would show a higher inductance than the chip using low temperature sintering $\mathrm{NiCuZn}$ ferrite.

The effect of $\mathrm{SiO}_{2}$ on the bending strength of $\mathrm{NiCuZn}$ ferrite was investigated by Aoki et al. [52]. They found that the bending strength of $\mathrm{NiCuZn}$ ferrite was increased by the addition of $\mathrm{SiO}_{2}$. The NiCuZn ferrite with $\mathrm{SiO}_{2}$ addition, showed a structure with smaller and more uniform grain size than non-addition of $\mathrm{SiO}_{2}$. The improvement in the bending strength of $\mathrm{NiCuZn}$ ferrite were attributed to the control of grain growth by $\mathrm{Zn}_{2} \mathrm{SiO}_{4}$ and the residual stress caused by the difference of coefficients of liner thermal expansion between ferrite phase and $\mathrm{Zn}_{2} \mathrm{SiO}_{4}$ phase. Kuroda [53] studied the phenomenological plasticity model accounting for hydrostatic stress sensitivity and vertex-type of effect.

The numerical simulation of the large elastic-plastic deformation behavior of hydrostatic stress-sensitivity in solids and numerical analysis and large strain elasticviscoplastic behaviour of hydrostatic stress-sensitive metals were carried out by Bruonig [54,55]. Bruonig et al. [56] also studied the numerical simulation of the localization behaviour of hydrostatic stress-sensitivity in metals.

Aoki et al. [57] carried out the studies on the bending strength of sintered $\mathrm{MgCuZn}, \mathrm{NiCuZn}$ and $\mathrm{MnZn}$ ferrites. They found that the much residual carbon content affects the bending strength of these sintered ferrites. Nakahata et al. [58] studied the low temperature $\mathrm{MgCuZn}$ ferrites.

Nakano et al. [59] studied the development of low temperature NiCuZn ferrites and study of high performance for multilayer chip ferrites and observed that the controlling stress by the internal Ag-conductor and $\mathrm{CuO}_{1-x} / \mathrm{Ag}$ on ferrites grain boundary is most important for high performance multilayer chip ferrites as well as the chemical composition of ferrite.

High strength $\mathrm{NiCuZn}$ ferrites used for surface mounting devices were studied by Murayamna et al. [60]. Temme et al. [61] studied the lithium ferrites for microwave devices. The effect of microstructure on residual stress-prodcuing a dreleasing mechanisms in $\mathrm{NiCuZn}$ ferrites by a non-destructive stress evealuation method using magnetic measurements was investigated bu Mian and Yamaguchi [62].

From the above review, the author noticed that the experimental work carried out on nickel magnesium copper and zinc ferrites is very scanty. In view of this, 
the author has taken up a systematic investigation on the effect of external stress on the inductance change in nickel magnesium copper and zinc ferrites and results are presented in next section.

\section{Experimental Details:}

In the present investigation, the three series of $\mathrm{NiMgCu}$ $\mathrm{Zn}$ ferrites were synthesized

Series I: $\mathrm{Ni}_{x} \mathrm{Mg}_{0.6-x} \mathrm{Cu}_{0.1} \mathrm{Zn}_{0.3} \mathrm{Fe}_{2} \mathrm{O}_{4}$ where $x$ varies from $0.0,0.1,0.2$ and 0.3

Series II: $\mathrm{Ni}_{0.3} \mathrm{Mg}_{x} \mathrm{Cu}_{0.1} \mathrm{Zn}_{0.6-x} \mathrm{Fe}_{2} \mathrm{O}_{4}$ where $x$ varies from $0.1,0.2$ and 0.3

Series III: $\mathrm{Ni}_{0.35} \mathrm{Mg}_{x} \mathrm{Cu}_{0.05} \mathrm{Zn}_{0.6-x} \mathrm{Fe}_{2} \mathrm{O}_{4}$ where $x$ varies from $0.0,0.1$ and 0.2

\subsection{Preparation of Ferrites}

In the present investigation, the $\mathrm{NiMgCuZn}$ ferrites were prepared by employing conventional solid state reaction route by mixing analytical grade $\mathrm{NiO}, \mathrm{MgO}, \mathrm{CuO}, \mathrm{ZnO}$ and $\mathrm{Fe}_{2} \mathrm{O}_{3}$ in stoichiometric proportions. These oxides were weighed and intimately mixed in appropriate proportions and ground together using agate mortar for 8 hours. This mixture was pressed into a cake and presintered at $800^{\circ} \mathrm{C}$ for 12 hours taking enough care to avoid the evaporation of zinc and is cooled to room temperature. The pre-sintered cake was crushed and was ground in agate mortar to obtain fine particle size. This powder was sieved to obtain uniform particle size.

These mixed powders were pressed with the help of the hydraulic press applying a pressure of $25 \mathrm{kN}$ using a high carbon high chromium steel die into the required shape. The binder used in the present work is $2 \%$ polyvinyl alcohol, dissolved in the water. Occasionally stearic acid dissolved in the acetone was also used as lubricant to prevent sticking of powder to the walls of the die to get the desired shape of the cylinders of diameter $10 \times 10^{-3} \mathrm{~m}$ and length nearly $20 \times 10^{-3} \mathrm{~m}$ at $150 \mathrm{MPa}$ which is the requirement shape of the experimental technique,

The green powders of the ferrites were pressed in suitable dies and they were loaded on a ceramic block containing ' $\mathbf{V}$ ' shaped grooves to prevent bending of the samples during the final sintering process at high temperatures. After loading the ceramic block in to the furnace, the temperature of the furnace was raised to $110^{\circ} \mathrm{C}$ in a period of $1 \mathrm{hr}$ and maintained at $110^{\circ} \mathrm{C}$ to remove the residual water content if any from the samples. Then the furnace temperature was raised to $800^{\circ} \mathrm{C}$ at the rate of $80^{\circ} \mathrm{C} / \mathrm{hr}$ and maintained there for one more hour for the burning of binder used in the samples. Lastly, the final temperature of $1250^{\circ} \mathrm{C}$ was achieved at the rate of $100^{\circ} \mathrm{C} / \mathrm{hr}$. A soaking time of $3 \mathrm{hrs}$ is maintained and later, the samples were cooled to room temperature at the rate of $80^{\circ} \mathrm{C} / \mathrm{hr}$. After cooling, the samples were removed from the furnace. Enough care was taken to avoid the evaporation of zinc during the sintering process. The samples were removed from the furnace and surfaces were ground to remove segregated layer if any and the measurement of physical parameters and characterization was carried out and the details are presented in the next section. All the samples were structurally characterized using Philips high resolution X-ray diffraction system (PM 1730 X-ray diffractometer). Microstructures of sintered samples were investigated using JOEL (Model HSM 35CF, Japan) scanning electron microscope.

The initial permeability, $\mu_{\mathrm{i}}$ of these ferrite torroids were evaluated using the standard formulae from the inductance measurements carried out at $1 \mathrm{kHz}$ using computer controlled impedance analyzer (Hioki Model 3532-50 LCR HiTester, Japan). These measurements were carried out in the temperature range of 30 to $400^{\circ} \mathrm{C}$. In order to study the effect of external stress, uniaxial compressive stress parallel to the magnetizing direction was applied to the cylindrical shaped ferrite cores using uniaxial press system. The stress magnitudes were varied from 0 to $10 \mathrm{MPa}$. The change in inductance was measured using the above mentioned LCR HiTester by employing 100 - 120 turns coil wound on each cylinder. The composite resonator technique [11] was employed for the room temperature longitudinal elastic modulus measurements.

\section{Results and Discussion}

Table 1 shows the details of various oxides present in the three series of $\mathrm{NiMgCuZn}$ ferrites in mole percent.

The typical X-ray diffractograms of NiMgCuZn ferrite samples of all the three series are shown Figures 1(a)-(j) depicts the typical X-ray diffractogram of $0.25 \mathrm{wt} \% \mathrm{SiO}_{2}$ added to sample-D. The X-ray diffraction analysis of the ferrite samples studied in the present work revealed the formation of all the peaks i.e. (220), (311), (222), (400), (422), (511) and (440) is the evident that the sintered samples contains only spinel phase cubic structure, no second phase was observed. Typical SEM patterns Sample A, Sample D and the $0.25 \mathrm{wt} \% \mathrm{SiO}_{2}$ added Sample D are shown in the Figures 2(a)-(c) respectively.

An examination of the SEM photographs reveals that the grain morphologies of the mentioned samples are different. A close examination of Figure 2(c)) reveals that there are large grains in this sample. Generally, large grained samples show high initial permeability magnitude. Addition of $\mathrm{SiO}_{2}$ to pure ferrite forms $\mathrm{Zn}_{2} \mathrm{SiO}_{4}$ as a second component as evidenced from the extra lines in the X-ray diffraction Figure 1(j) also it may be pointed out here that this second phase is not visible in the scanning electron micrograph shown in Figure 2(c)). It 
Table 1. Composition of various oxides present in NiMgCuZn ferrites in mole percent.

\begin{tabular}{|c|c|c|c|c|c|c|}
\hline S.No. & Sample & $\mathrm{NiO}$ & $\mathrm{MgO}$ & $\mathrm{CuO}$ & $\mathrm{ZnO}$ & $\mathrm{Fe}_{2} \mathrm{O}_{3}$ \\
\hline \multicolumn{7}{|l|}{ Series I } \\
\hline 1. & A & 0 & 30 & 5 & 15 & 50 \\
\hline 2. & B & 5 & 25 & 5 & 15 & 50 \\
\hline 3. & $\mathrm{C}$ & 10 & 20 & 5 & 15 & 50 \\
\hline 4. & $\mathrm{D}$ & 15 & 15 & 5 & 15 & 50 \\
\hline \multicolumn{7}{|l|}{ Series II } \\
\hline 5. & $\mathrm{E}$ & 15 & 5 & 5 & 25 & 50 \\
\hline 6. & F & 15 & 10 & 5 & 20 & 50 \\
\hline \multicolumn{7}{|c|}{ Series III } \\
\hline 8. & $\mathrm{H}$ & 17.5 & 0 & 2.5 & 30 & 50 \\
\hline 9. & I & 17.5 & 5 & 2.5 & 25 & 50 \\
\hline 10. & $\mathrm{~J}$ & 17.5 & 10 & 2.5 & 20 & 50 \\
\hline
\end{tabular}

Series I: $\mathrm{A}-\mathrm{Ni}_{0.0} \mathrm{Mg}_{0.6} \mathrm{Cu}_{0.1} \mathrm{Zn}_{0.3} \mathrm{Fe}_{2} \mathrm{O}_{4}, \mathrm{~B}-\mathrm{Ni}_{0.1} \mathrm{Mg}_{0.5} \mathrm{Cu}_{0.1} \mathrm{Zn}_{0.3} \mathrm{Fe}_{2} \mathrm{O}_{4}, \mathrm{C}-\mathrm{Ni}_{0.2} \mathrm{Mg}_{0.4} \mathrm{Cu}_{0.1} \mathrm{Zn}_{0.3} \mathrm{Fe}_{2} \mathrm{O}_{4}, \mathrm{D}_{-}-\mathrm{Ni}_{0.3} \mathrm{Mg}_{0.3} \mathrm{Cu}_{0.1} \mathrm{Zn}_{0.3} \mathrm{Fe}_{2} \mathrm{O}_{4} ; \mathrm{Series} \mathrm{II}: \mathrm{E}-\mathrm{Ni}_{0.3}$ $\mathrm{Mg}_{0.1} \mathrm{Cu}_{0.1} \mathrm{Zn}_{0.5} \mathrm{Fe}_{2} \mathrm{O}_{4}, \mathrm{~F}-\mathrm{Ni}_{0.3} \mathrm{Mg}_{0.2} \mathrm{Cu}_{0.1} \mathrm{Zn}_{0.4} \mathrm{Fe}_{2} \mathrm{O}_{4}, \mathrm{G}-\mathrm{Ni}_{0.3} \mathrm{Mg}_{0.3} \mathrm{Cu}_{0.1} \mathrm{Zn}_{0.3} \mathrm{Fe}_{2} \mathrm{O}_{4}$; Series III: $\mathrm{H}-\mathrm{Ni}_{0.35} \mathrm{Mg}_{0.0} \mathrm{Cu}_{0.05} \mathrm{Zn}_{0.6} \mathrm{Fe}_{2} \mathrm{O}_{4}, \mathrm{I}_{-}-\mathrm{Ni}_{0.35} \mathrm{Mg}_{0.1} \mathrm{Cu}_{0.05} \mathrm{Zn}_{0.5-}$ $\mathrm{Fe}_{2} \mathrm{O}_{4}, \mathrm{~J}-\mathrm{Ni}_{0.35} \mathrm{Mg}_{0.2} \mathrm{Cu}_{0.05} \mathrm{Zn}_{0.4} \mathrm{Fe}_{2} \mathrm{O}_{4}$.

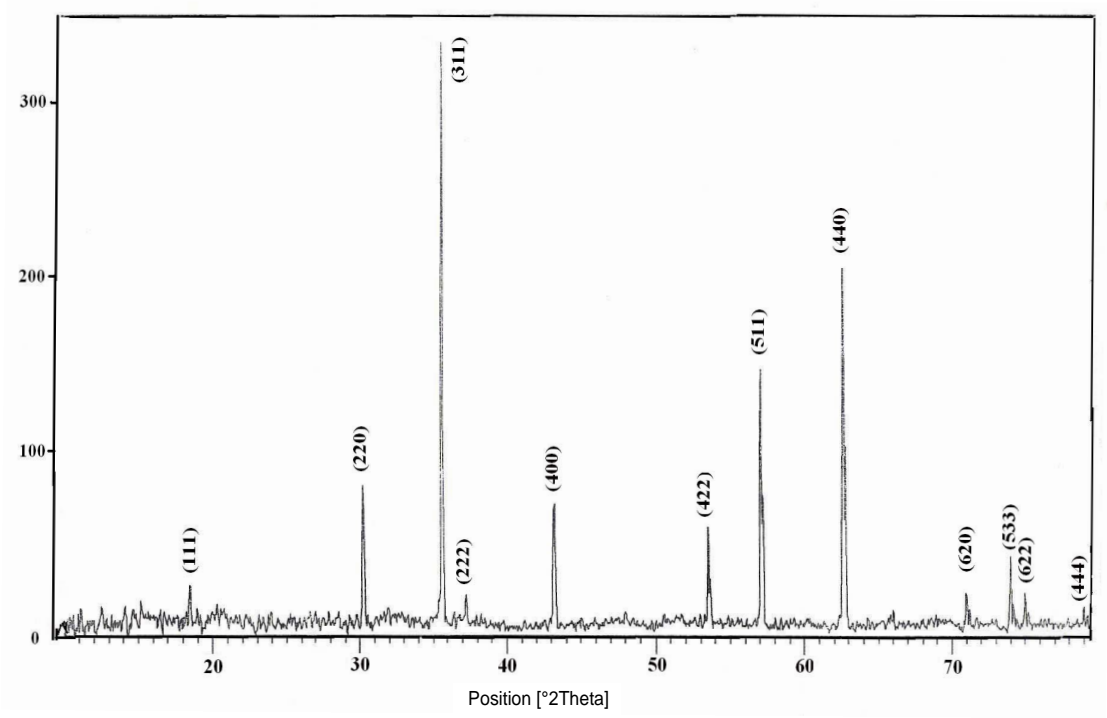

(a)

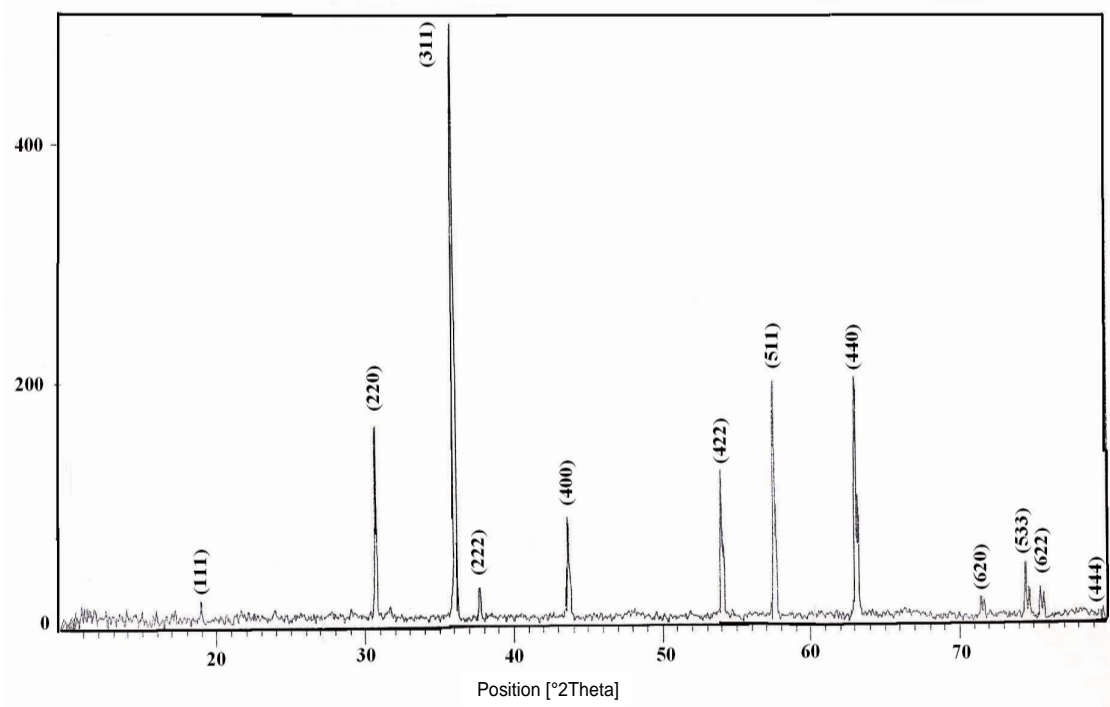

(b) 


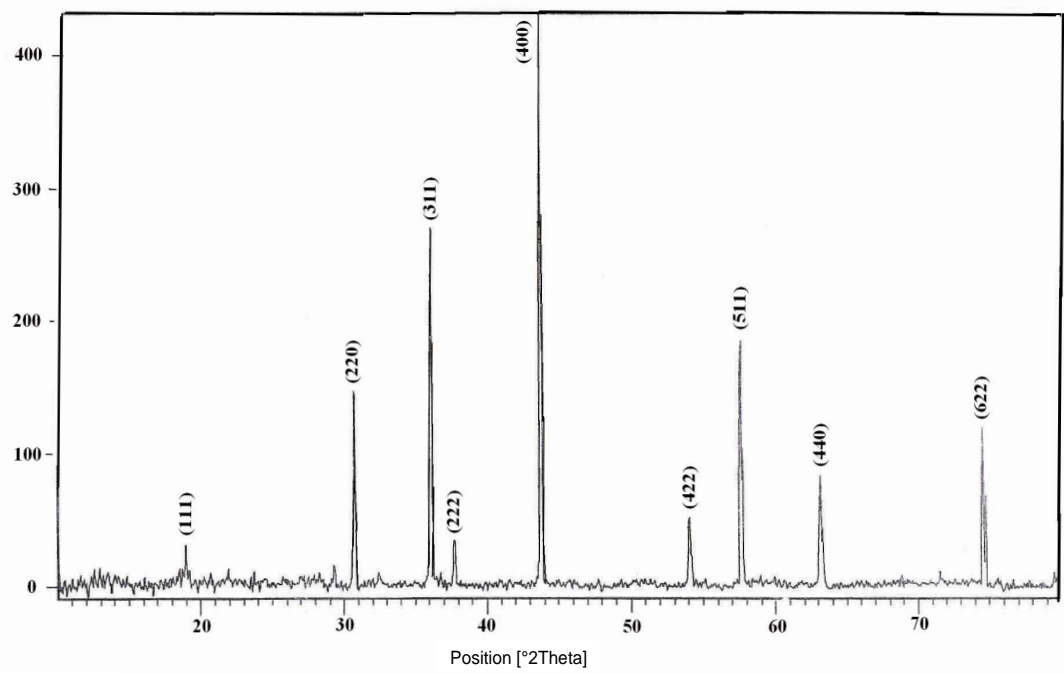

(c)

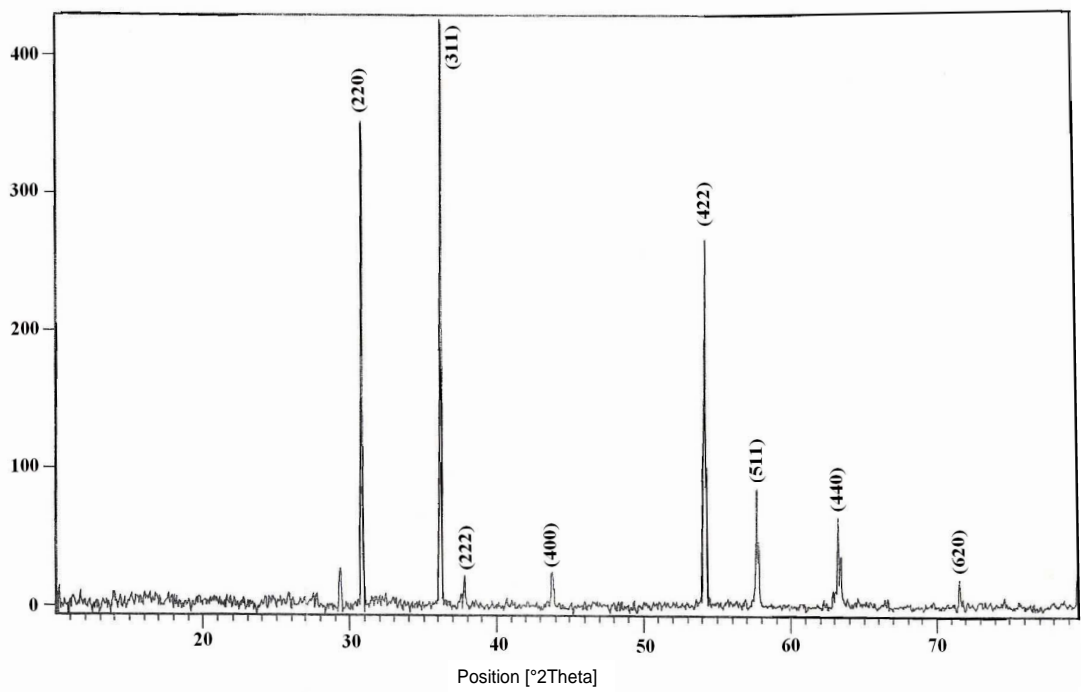

(d)

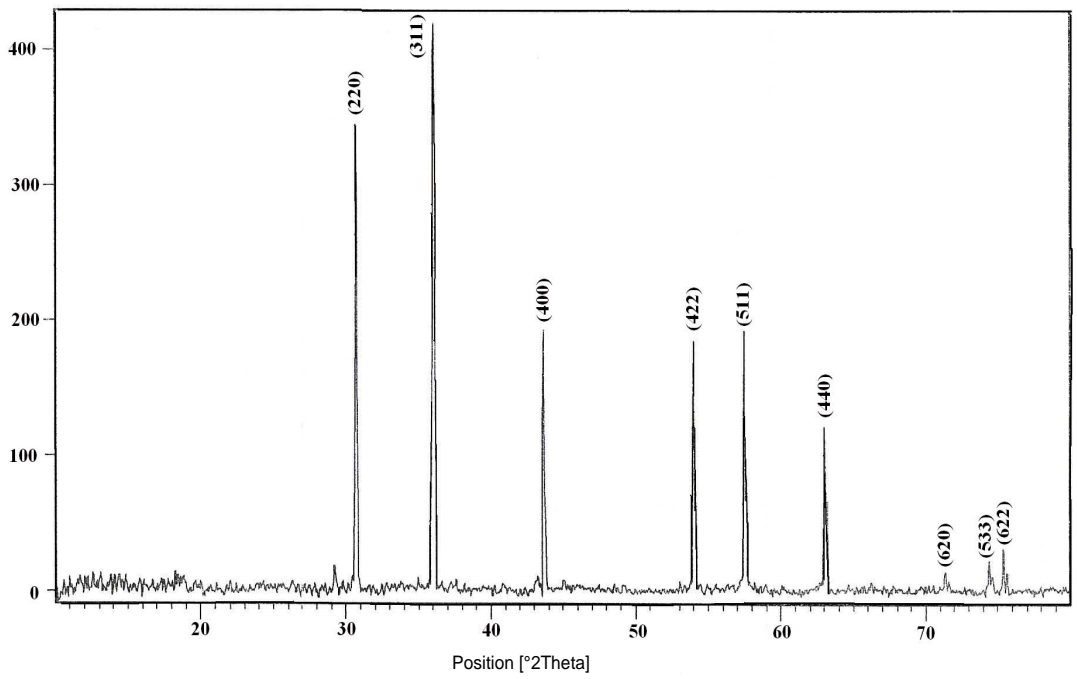

(e) 


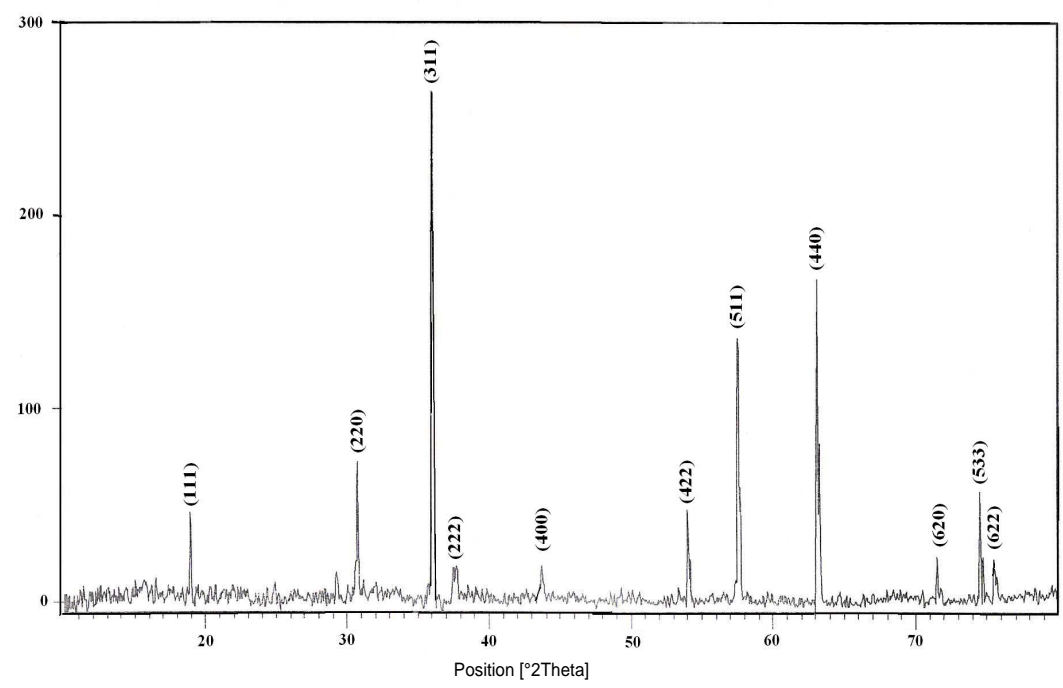

(f)

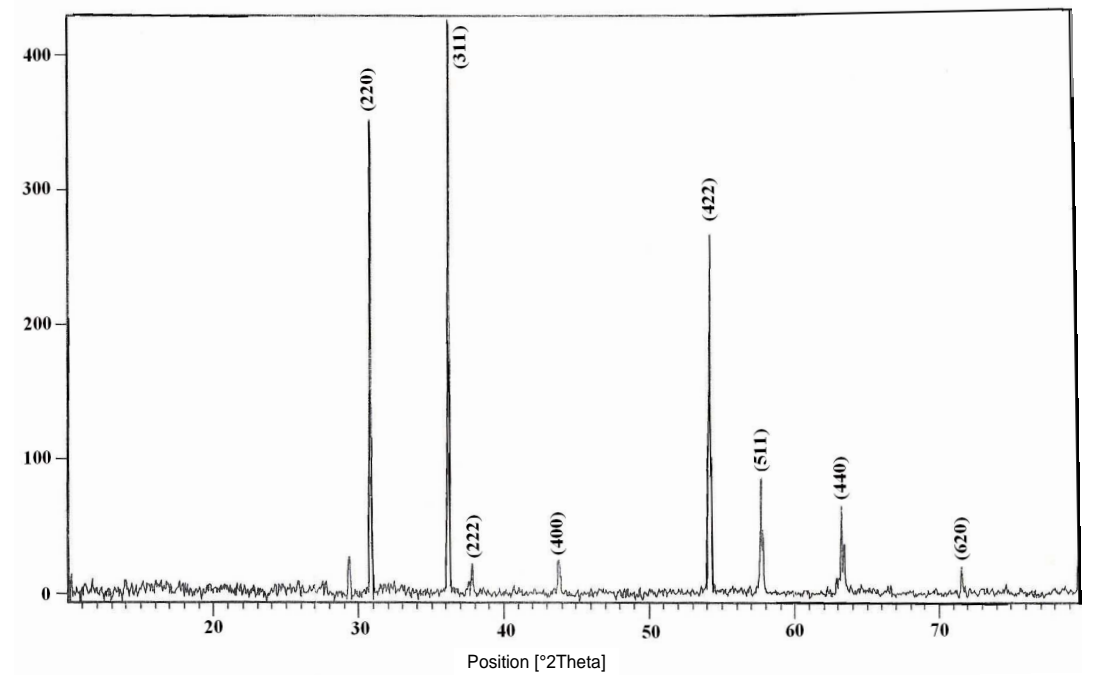

(g)

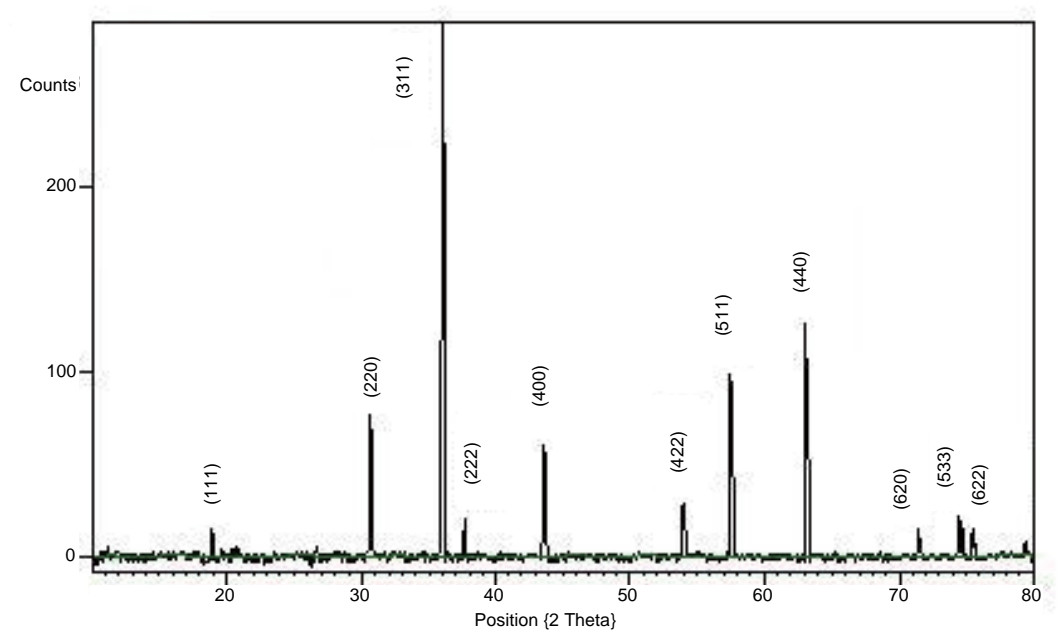

(h) 


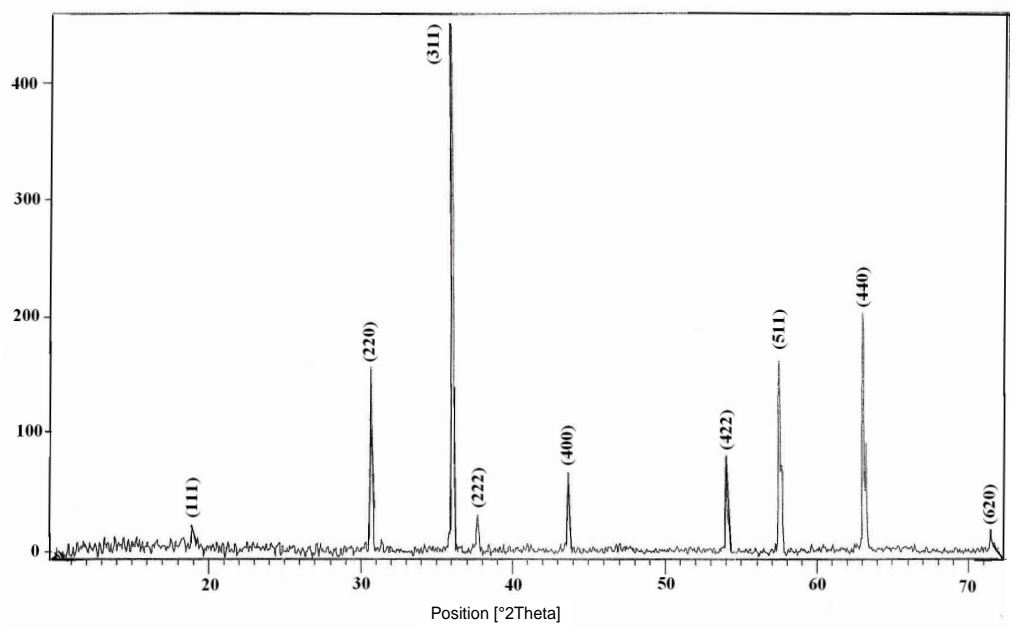

(i)

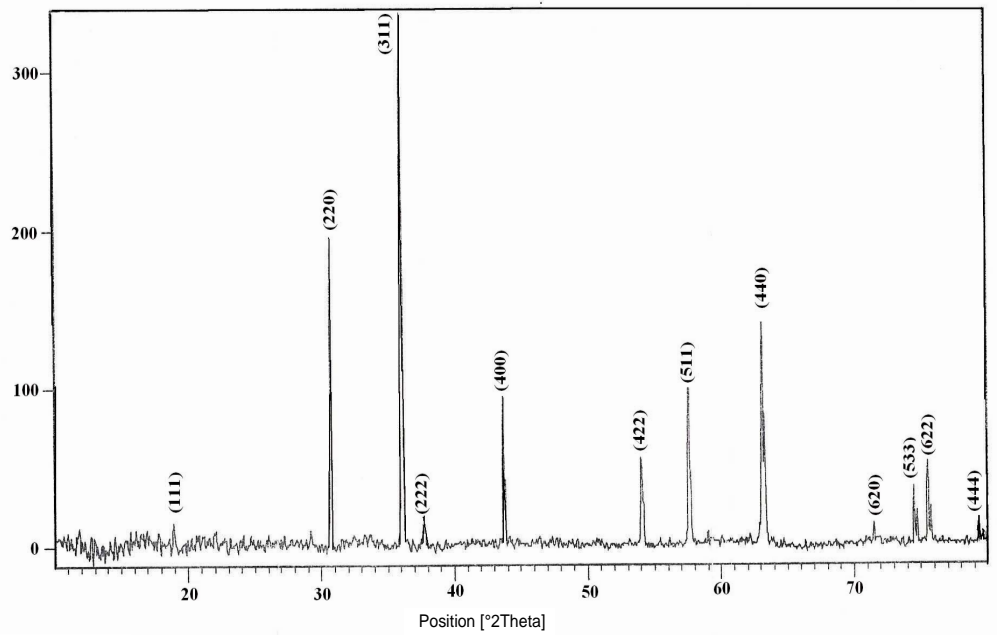

(j)

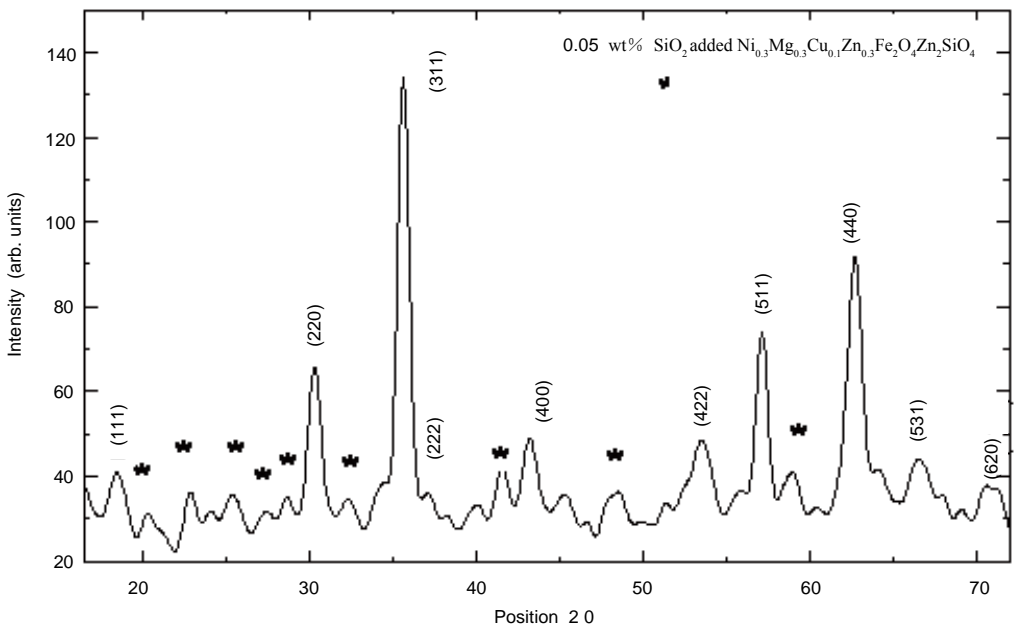

(k)

Figure 1. (a) X-ray diffractogram of Sample A; (b) X-ray diffractogram of Sample B; (c) X-ray diffractogram of Sample C; (d) X-ray diffractogram of Sample D; (e) X-ray diffractogram of Sample E; (f) X-ray diffractogram of Sample F; (g) X-ray diffractogram of Sample G; (h) X-ray diffractogram of Sample H; (i) X-ray diffractogram of Sample I; (j) X-ray diffractogram of Sample J; (k) X-ray diffractogram of $\mathrm{SiO}_{2}$ added Sample D. 


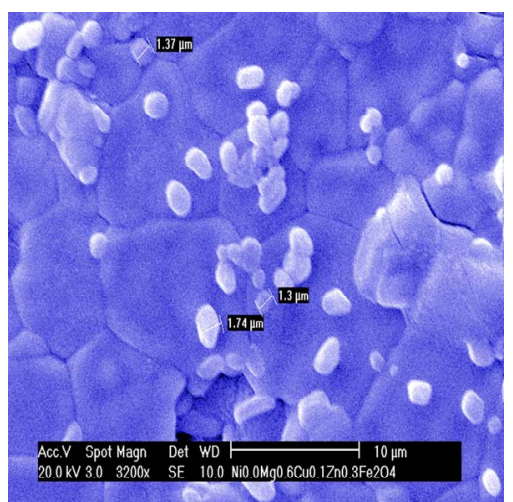

(a)

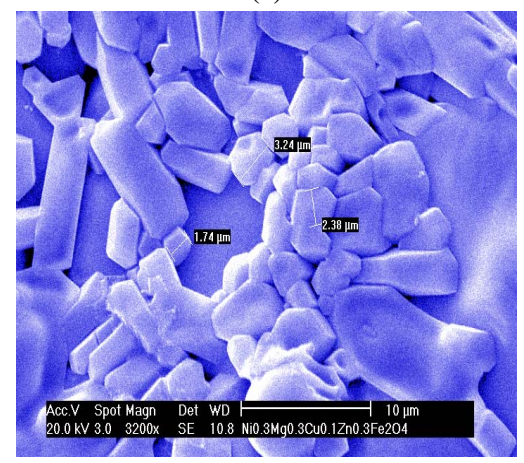

(b)

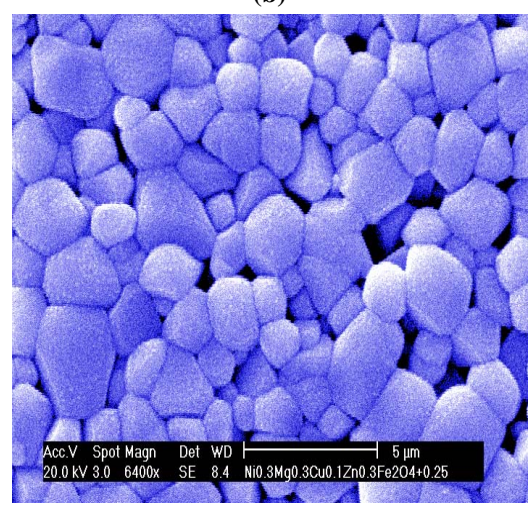

(c)

Figure 2. Scanning electron micrographs of (a) Sample A; (b) Sample D; (c) $\mathrm{SiO}_{2}$ added Sample D.

appears that $\mathrm{Zn}_{2} \mathrm{SiO}_{4}$, a non-magnetic material seems to cover the grains of the ferrite to act mechanically against the external compressive stress and act as a buffer material in reducing the stress sensitivity considerably.

\section{(a) Series I}

Table 2 shows the values of compositional dependence of initial permeability at room temperature at $1 \mathrm{KHz}$. The variation of initial permeability $\left(\mu_{i}\right)$ with temperature, the composition in which there is no nickel content i.e., Sample A shows a value of initial permeability $\left(\mu_{i}=\right.$ 585 at $30^{\circ} \mathrm{C}$ ) and Curie temperature $T_{c}=230^{\circ} \mathrm{C}$, while the Sample D shows an initial permeability magnitude of $\left(\mu_{i}=518\right.$ at $\left.30^{\circ} \mathrm{C}\right)$ and has a high Curie temperature $T_{c}=$ $300^{\circ} \mathrm{C}$. It can be inferred from this that the magnitudes of initial permeability at room temperature are moderate high.

Figure 3 shows the graphically represented data of the ratio of inductance change $(\Delta \mathrm{L} / \mathrm{L}) \%$ as a function of applied compressive stress for Sample A. An examination of the Figure 3 indicates that $(\Delta \mathrm{L} / \mathrm{L}) \%$ increases up to a certain applied stress and there after, it decreases, showing different stress sensitivities for different compositions.

It is clear from figure that ratio of change in inductance $(\Delta \mathrm{L} / \mathrm{L}) \%$ reaches a peak value and then starts decreasing with increasing applied compressive stress for all the compositions, but it is found to be less stress sensitive in composition Sample D In all the samples studied in this series the $(\Delta \mathrm{L} / \mathrm{L}) \%$ values are positive in the entire region of the applied stress applied. Exactly, similar behaviour was noticed by Kanada et al. [36] in NiMg $\mathrm{CuZn}$ ferrites at $4 \mathrm{Mpa}$.

Table 2. Lattice parameter, density, Curie temperature and Initial Permeability of all the three series of NiMgCuZn ferrites at room temperature.

\begin{tabular}{cccccc}
\hline S.No & Sample & $\begin{array}{c}\text { Lattice } \\
\text { Parameter } \\
(\AA)\end{array}$ & $\begin{array}{c}\text { Density } \\
\mathrm{kg} \cdot \mathrm{m}^{-3}\end{array}$ & $\begin{array}{c}\text { Curie Tempera- } \\
\text { ture } \mathrm{T}_{\mathrm{C}}\left({ }^{\circ} \mathrm{C}\right)\end{array}$ & $\begin{array}{c}\text { Initial Perme- } \\
\text { ability }\left(\mu_{i}\right)\end{array}$ \\
\hline 1 & $\mathrm{~A}$ & 8.374 & 4.267 & 230 & 585 \\
2 & $\mathrm{~B}$ & 8.274 & 4.442 & 270 & 575 \\
3 & $\mathrm{C}$ & 8.255 & 4.665 & 290 & 525 \\
4 & $\mathrm{D}$ & 8.234 & 5.321 & 300 & 518 \\
5 & $\mathrm{E}$ & 8.260 & 4.498 & 210 & 1351 \\
6 & $\mathrm{~F}$ & 8.252 & 4.534 & 280 & 703 \\
7 & $\mathrm{G}$ & 8.234 & 5.321 & 300 & 519 \\
8 & $\mathrm{H}$ & 8.314 & 5.568 & 190 & 1041 \\
9 & $\mathrm{I}$ & 8.255 & 4.742 & 220 & 596 \\
10 & $\mathrm{~J}$ & 8.247 & 4.459 & 290 & 336 \\
\hline
\end{tabular}

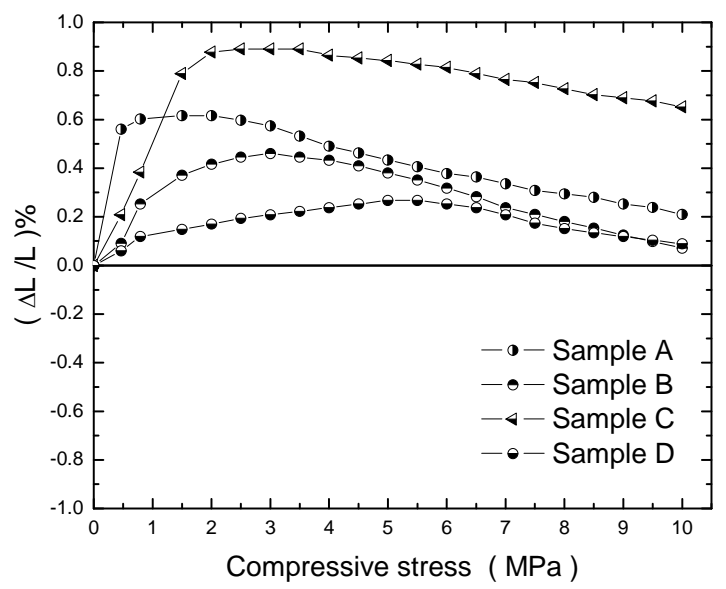

Figure 3. Variation of ratio of change in inductance $(\Delta \mathrm{L} / \mathrm{L}) \%$ as a function of applied compressive stress in Series I system. 
These curves show peak values of $(\Delta \mathrm{L} / \mathrm{L}) \%$ at different magnitudes of external compressive stresses. As the elastic modulus of the ferrite increases the material becomes less compressive and the stress variation is found to decrease. This is in agreement with the observations made by Kumagai and Ikeda [18]. For small compressive stresses, the stress raises initial permeability with negative magnetostriction and for large tensile stresses the permeability decreases [63]. The variations of permeability with applied stress can be attributed to the magnetostrictive contributions of varied amounts of nickel and iron present in these samples.

\section{(b) Series II}

The initial permeability $\left(\mu_{i}\right)$ for Sample E shows high value of initial permeability $\left(\mu_{i}=1351\right.$ at $\left.30^{\circ} \mathrm{C}\right)$ and $\mathrm{Cu}-$ rie temperature $\left(T_{c}=210^{\circ} \mathrm{C}\right)$, while the sample Sample $\mathrm{G}$ has fairly high Curie temperature $\left(T_{c}=300^{\circ} \mathrm{C}\right)$, and shows low permeability value $\mu_{i}=518$ at room temperature presented in Table 2

The variation of ratio of inductance change $(\Delta \mathrm{L} / \mathrm{L}) \%$ as a function of applied compressive stress is shown in Figure 4.

An examination of the Figure 4 it is clear that $(\Delta \mathrm{L} / \mathrm{L}) \%$ increases up to a certain applied stress and there after, it decreases, showing different stress sensitivities for different compositions.

\section{(c) Series III}

The values of initial permeability of this series at room temperature is given in Figure 2 which shows a high permeability i.e. 1041 for sample $\mathrm{H}$ and low value i.e. 336 for Sample J

The variation of ratio of inductance change $(\Delta \mathrm{L} / \mathrm{L}) \%$ as a function of applied compressive stress is shown in

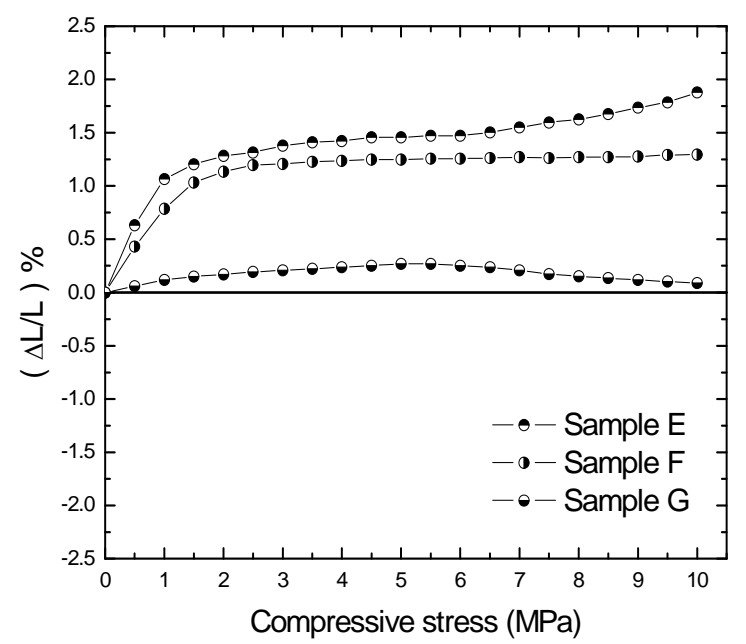

Figure 4. Variation of ratio of change in inductance $(\Delta \mathrm{L} / \mathrm{L}) \%$ as a function of applied compressive stress in Series II system.
Figure 5. From this it is clear that $(\Delta \mathrm{L} / \mathrm{L}) \%$ increases up to a certain applied stress and there after, starts decreasing, showing different stress sensitivities for different compositions. It can be seen from Figure 5 for $x=0.0$ $(\Delta \mathrm{L} / \mathrm{L}) \%$ values are negative in the entire region of stress applied while for $x=0.1$ and $0.2(\Delta \mathrm{L} / \mathrm{L}) \%$ values are positive in the entire region of stress applied.

Among all the three series studied in the present work, it can be noticed that in Sample D the stress sensitivity is found to be less. It is thought that in view of the stress insensitivity could be achieved in these above mentioned ferrite by employing suitable additives.

However, the stress sensitivity in these ferrites is fairly low compared to NiCuZn ferrites [19]. These $(\Delta \mathrm{L} / \mathrm{L}) \%$ curves with applied compressive stress show peak values [36] at different magnitudes of external compressive stress. These variations of permeability with applied compressive stress can be attributed to the magnetostrictive contributions of varied amounts of nickel $\left(\lambda_{s}=-26 \times\right.$ $\left.10^{-6}\right)$, and iron $\left(\lambda_{s}=-19.5 \times 10^{-6}\right)$ present in these samples [48]. For small compressive stresses, the stress raises initial permeability with negative magnetostriction and for large tensile stresses the permeability decreases [63].

\section{Achievement of Stress Insensitivity of Ferrites for Micro-Inductor Applications}

To examine the effect of various additives on the reduction of stress sensitivity of these $\mathrm{NiMgCuZn}$ ferrites, addition of various additives like $\mathrm{MgO}, \mathrm{Bi}_{2} \mathrm{O}_{3} \mathrm{~B}_{2} \mathrm{O}_{3}$ and $\mathrm{SiO}_{2}$ were examined. Among these additives, it was found that addition of $\mathrm{SiO}_{2}$ was found to be beneficial effect in reducing the stress sensitivity in these ferrites.

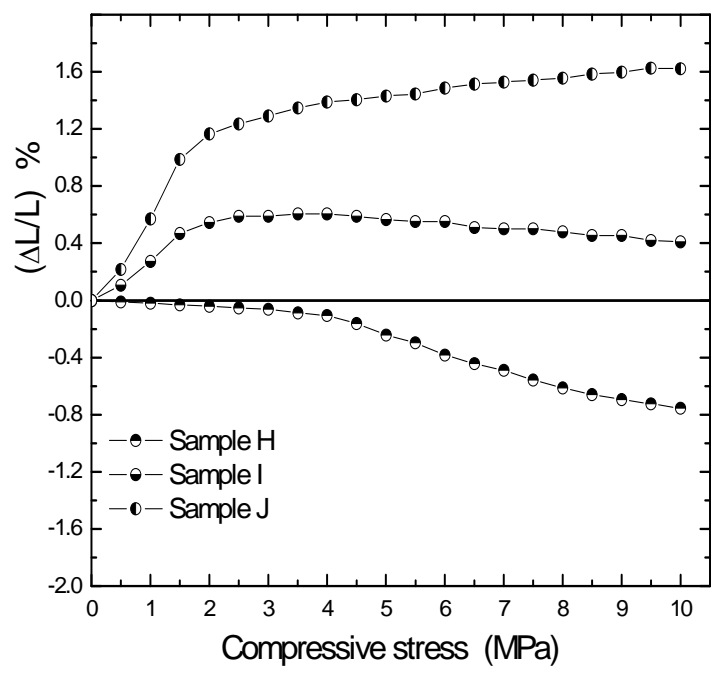

Figure 5. Variation of ratio of change in inductance $(\Delta \mathrm{L} / \mathrm{L})$ $\%$ as a function of applied compressive stress in Series III system. 
Hence to reduce the stress sensitivity in these $\mathrm{NiMg}$ $\mathrm{CuZn}$ ferrites, the composition from Series I (viz., Sample i.e. $\mathrm{Ni}_{0.3} \mathrm{Mg}_{0.3} \mathrm{Cu}_{0.1} \mathrm{Zn}_{0.3} \mathrm{Fe}_{2} \mathrm{O}_{4}$ in which stress sensitivity is found to be less, was chosen and different amounts of $\mathrm{SiO}_{2}(0.05 \mathrm{wt} \%$ to $2 \mathrm{wt} \%)$ were added to it as an additive and a series of ferrites were prepared. The stress sensitivity in these ferrites was examined.

Figure 6 shows the temperature variation of initial permeability $\mu_{i}$ at $1 \mathrm{kHz}$ in the temperature range of 30 to $350^{\circ} \mathrm{C}$ of pure ferrite sample $\mathrm{D}$ and those samples obtained by addition of various contents of $\mathrm{SiO}_{2}$ to it. At room temperature, the magnitude of initial permeability $\mu_{i}$ vary between 530 and 340 with increasing content of $\mathrm{SiO}_{2}$. It can be noticed from the figure that the magnitude of Curie temperature does not change much with addition of $\mathrm{SiO}_{2}$.

To examine the effect of addition of $\mathrm{SiO}_{2}$ (from $0.05 \mathrm{wt} \%$ to $2 \mathrm{wt} \%$ ) on the variation of ratio of inductance change $(\Delta \mathrm{L} / \mathrm{L}) \%$ as a function of compressive stress in the sample $\mathrm{D}$ and the samples obtained by adding different contents of $\mathrm{SiO}_{2}$ to it, the $(\Delta \mathrm{L} / \mathrm{L}) \%$ measurements were carried out with increasing compressive stress and the data is graphically in Figure 7. It can be noticed from Figure 7 that the ratio of $(\Delta \mathrm{L} / \mathrm{L}) \%$ increases with increasing applied stress in pure ferrite. As the addition of $\mathrm{SiO}_{2}$ increases, $(\Delta \mathrm{L} / \mathrm{L}) \%$ magnitude changes from positive to negative. The $(\Delta \mathrm{L} / \mathrm{L}) \%$ decreases slowly at lower stress magnitudes and at higher stress magnitudes the fall in $(\Delta \mathrm{L} / \mathrm{L}) \%$ is more in $\mathrm{SiO}_{2}$ added samples. However, it can be observed that the variation of ratio of inductance change $(\Delta \mathrm{L} / \mathrm{L}) \%$ is almost negligible within the experimental error in the case of the sample with $0.05 \mathrm{wt} \%$ $\mathrm{SiO}_{2}$. That is, the ferrite becomes stress insensitive at this composition.

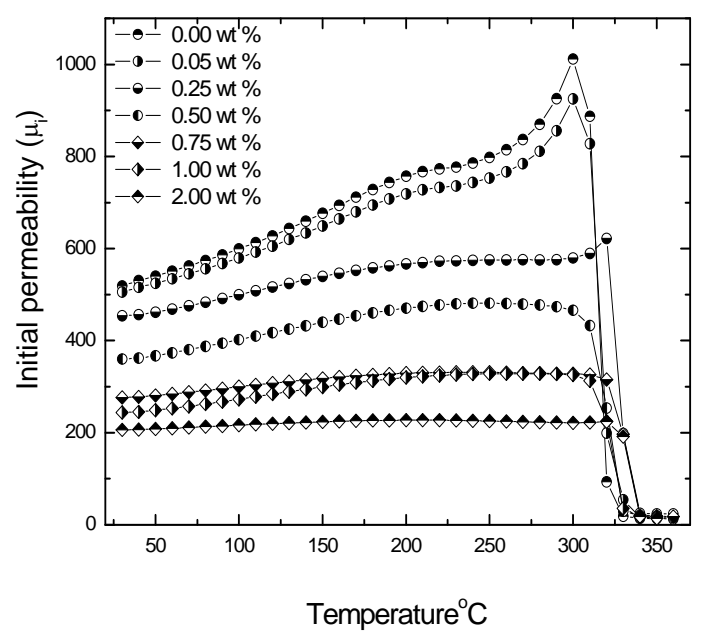

Figure 6. The variation of initial permeability $\left(\mu_{i}\right)$ at room temperature for $\mathrm{SiO}_{2}$ added Sample $\mathrm{D}$ system at $1 \mathrm{kHz}$.
In order to understand the stress sensitivity behaviour, measurements of longitudinal modulus (L) were carried out on sample $\mathrm{D}$ and those obtained by adding various amounts of $\mathrm{SiO}_{2}$ as additive. The variation of longitudinal modulus $\mathrm{L}$, as a function of $\mathrm{SiO}_{2}$ concentration is shown in Figure 8.

An examination of the Figure 8 reveals that when $\mathrm{SiO}_{2}$ is added to the ferrite sample the modulus increases sharply and remains fairly constant at higher magnitudes of $\mathrm{SiO}_{2}$. This shows that the addition of $\mathrm{SiO}_{2}$ to ferrite sample enhances the modulus indicating that the sample is becoming stress insensitive. Addition of $\mathrm{SiO}_{2}$ to pure ferrite forms $\mathrm{Zn}_{2} \mathrm{SiO}_{4}$ as a second component as evidenced from the extra lines in the X-ray diffraction Figure 1(j). It may be pointed out here that this second phase is not visible in the scanning electron micrograph shown in Figure 2(c). It appears that $\mathrm{Zn}_{2} \mathrm{SiO}_{4}$, a

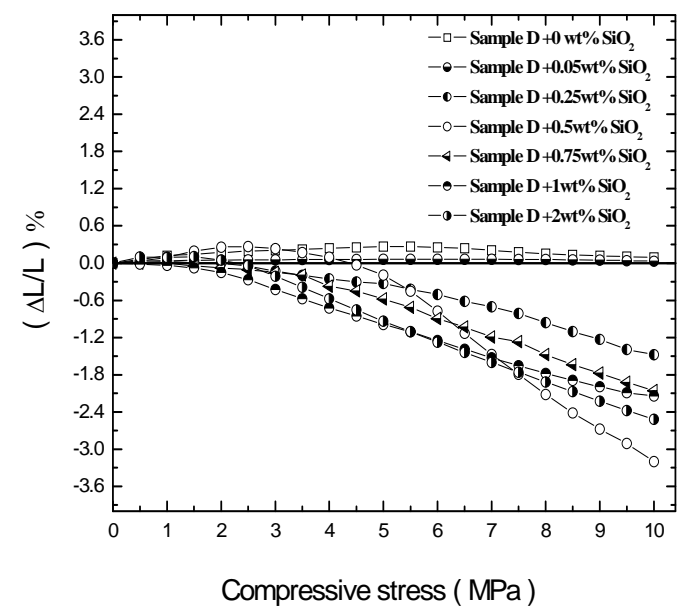

Figure 7. Variation of ratio of change in inductance $(\Delta \mathrm{L} / \mathrm{L})$ $\%$ as a function of applied compressive stress in $\mathrm{SiO}_{2}$ added Sample D system.

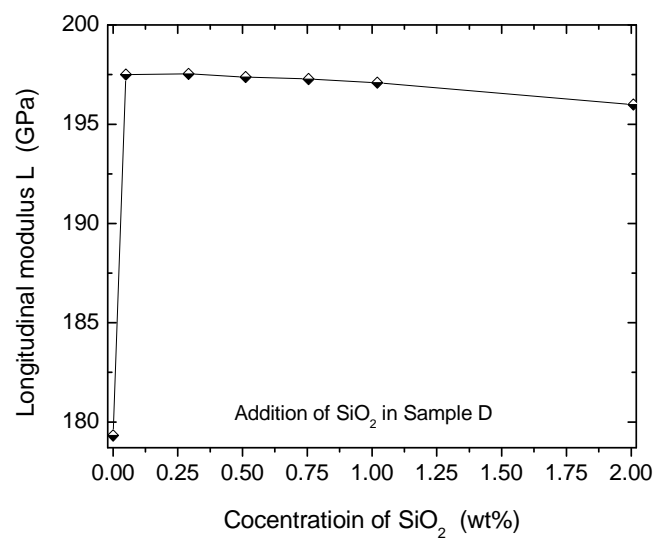

Figure 8. Variation of longitudinal modulus (L) as a function of $\mathrm{SiO}_{2}$ concentration in Sample $\mathrm{D}$ system. 
non-magnetic material seems to cover the grains of the ferrite to act mechanically against the external compressive stress and act as a buffer material in reducing the stress sensitivity considerably.

The work is aimed at obtaining nickel magnesium copper and zinc ferrites with constant magnetic permeability and stress insensitive with various additives like $\mathrm{MgO}, \mathrm{Bi}_{2} \mathrm{O}_{3} \mathrm{~B}_{2} \mathrm{O}_{3}$ and $\mathrm{SiO}_{2}$ were examined. Among the additives mentioned above, it was found that addition of $\mathrm{SiO}_{2}$ has beneficial effect in reducing the stress sensitivity in these ferrites. The permeability is reasonably high for $\mathrm{SiO}_{2}$ concentration for $0.05 \mathrm{wt} \%$. Addition of $\mathrm{SiO}_{2}$ to $\mathrm{NiMgCuZn}$ ferrite causes reduction of stress sensitivity. In the present work on NiMgCuZn and Pure NiCuZn ferrites it is found that the addition of $0.05 \mathrm{wt} \% \mathrm{SiO}_{2}$ in sample D produces stress insensitivity.

\section{Comparison of the Results:}

\begin{tabular}{|c|c|c|c|c|}
\hline No & Author Name & Ref. No. & Studies Carried Out & Observations/Conclusions \\
\hline 1. & $\begin{array}{l}\text { Ramamanohar } \\
\text { Reddy et al. }\end{array}$ & [19] & $\begin{array}{l}\text { Stress sensitivity of inductance in } \\
\mathrm{NiCuZn} \text { ferrites }\end{array}$ & $\begin{array}{l}\text { Stress sensitivity is more in the case of } \\
\text { iron rich and stoichiometric iron samples } \\
\text { while in the case of iron deficient samples } \\
\text { the stress sensitivity was found to be less. }\end{array}$ \\
\hline 3. & Kaczkowski & [35] & $\begin{array}{l}\text { The stress sensitivity in Ni-Mn, } \\
\text { Ni-Mn-Co and Ni-Mn-Co-Cu fer- } \\
\text { rites }\end{array}$ & $\begin{array}{l}\text { The high stress sensitivity was observed } \\
\text { for the ferrites with the smallest magne- } \\
\text { tocrystalline anisotropy }\end{array}$ \\
\hline 4. & Kanada et al. & {$[36]$} & $\begin{array}{l}\text { The effects of chemical composition } \\
\text { and micro structure on stress sensi- } \\
\text { tivity of magnetic properties with } \\
\text { applied stress in Ni-Mg-Cu-Zn fer- } \\
\text { rite materials were investigated, }\end{array}$ & $\begin{array}{l}\text { They found that the application of exter- } \\
\text { nal stress reduces the permeability }\end{array}$ \\
\hline 5. & Ikeda and Kumagi & [48] & $\begin{array}{l}\text { Developments of stress-insensitive } \\
\text { ferrite }\end{array}$ & $\begin{array}{l}\text { The sensitivity of the magnetic property } \\
\text { to the external stress in NiCuZn ferrite } \\
\text { was examined from the relationship be- } \\
\text { tween stress and permeability. } \\
\text { Controlling stress by the internal }\end{array}$ \\
\hline 6. & Nakano et al. & [49] & $\begin{array}{l}\text { Development of low temperature } \\
\text { fired NiCuZn ferrites and studied } \\
\text { the high performance multilayer } \\
\text { chip inductors }\end{array}$ & $\begin{array}{l}\mathrm{Ag} \text {-conductor and } \mathrm{CuO}_{1-\mathrm{x}} / \mathrm{Ag} \text { on ferrites } \\
\text { grain boundary is most important key } \\
\text { point for high performance multilayer } \\
\text { chip ferrites as well as the chemical } \\
\text { composition of ferrites. }\end{array}$ \\
\hline
\end{tabular}

The magnetic properties of $\mathrm{Mg}-\mathrm{Cu}-\mathrm{Zn}$ ferrites under stress were

7. Nakano et al.

8. Aoki et al.

9. Aoki et al.

10. Nakano et al.

11. Aoki et al.

12. Varalaxmi et al. investigated and compared with $\mathrm{Ni}-\mathrm{Cu}-\mathrm{Zn}$ ferrite under a compressive stress.

The effect of $\mathrm{SiO}_{2}$ on the bending strength of NiCuZn ferrite The studies on the bending strength of sintered $\mathrm{MgCuZn}, \mathrm{NiCuZn}$, and MnZn ferrites.

The development of low temperature NiCuZn ferrites and study of high performance for multilayer chip ferrites

The stress sensitivity in Ni-Mn, $\mathrm{Ni}-\mathrm{Mn}-\mathrm{Co}$ and Ni-Mn-Co-Cu ferrites

Stress sensitivity of inductance in $\mathrm{NiMgCuZn}$ ferrites and development of a stress insensitive ferrite composition for microinductors
The change in permeability with stress of low temperature sintered $\mathrm{MgCuZn}$ ferrite was lower than that of low temperature sintered $\mathrm{NiCuZn}$ ferrite.

The bending strength of NiCuZn ferrite was increased by the addition of $\mathrm{SiO}_{2}$. The much residual carbon content affects the bending strength of these sintered ferrites.

The controlling stress by the internal $\mathrm{Ag}$-conductor and $\mathrm{CuO}_{1-x} / \mathrm{Ag}$ on ferrites grain boundary is most important for high performance multilayer chip ferrites as well as the chemical composition of ferrite the greatest stress sensitivity was observed for the ferrites with the smallest magnetocrystalline anisotropy

The addition of $0.05 \mathrm{wt} \% \mathrm{SiO}_{2}$ in sample $\mathrm{Ni}_{0.3} \mathrm{Mg}_{0.3} \mathrm{Cu}_{0.1} \mathrm{Zn}_{0.3} \mathrm{Fe}_{2} \mathrm{O}_{4}$ produces stress insensitivity. 


\section{Acknowledgments}

This work was financially supported by Defence Research and Development Organization (DRDO), under the grants ERIP/ER/0103301/M/01, New Delhi, India. The authors are thankful to the authorities of Sri Krishnadevaraya University, Anantapur for providing the facilities to carry out this programme.

\section{REFERENCES}

[1] X. Qi, J. Zhou, Z. Yue, Z. Gui and L. Li. Key, "Room Temperature Preparation of Nanocrystalline $\mathrm{MnCuZn}$ Ferrite Powder by Auto-Combustion of Nitrate-Citrate," Key Engineering Materials, Vol. 224-226, 2002, pp. 593596. doi:10.4028/www.scientific.net/KEM.224-226.593

[2] T. Nakamura, Y. Okano and S. Miura, "Interfacial Diffusion between Ni-Zn-Cu Ferrite and Ag during Sintering," Journal of Materials Science, Vol. 33, No. 4, 1998, pp. 1091-1094. doi:10.1023/A:1004344719076

[3] J. Y. Hsu, W. S. Ko, H. D. Shen and C. J. Chen, "Low Temperature Fired NiCuZn Ferrite," IEEE Transactions on Magnetics, Vol. 30, No. 6, 1994, pp. 4875-4877. doi: $10.1109 / 20.334251$

[4] S. F. Wang, Y. R. Wang, T. C. K. Yang, P. J. Wang and C. A. Lu, "Densification and Properties of Fluxed Sintered NiCuZn Ferrites," Journal of Magnetism and Magnetic Materials, Vol. 217, No. 1-3, 2000, pp. 35-43. doi:10.1016/S0304-8853(00)00325-5

[5] T. Y. Byun, S. C. Beyon, K. S. Hong and C .K. Kim, "Origin of Line Broadening in Co-substituted $\mathrm{NiZnCu}$ Ferrites," Journal of Applied Physics, Vol. 87, No. 9, 2000, pp. 6220-6222. doi:10.1063/1.372660

[6] J.-H. Nam, W.-G. Hur and J.-H. Oh, "The Effect of Mn Substitution on the Properties of NiCuZn Ferrites," Journal of Applied Physics, Vol. 81, No. 7, 1997, pp. 47944796. doi:10.1063/1.365466

[7] Z. Yue, J. Zhou, L. Li and Z. Gui, "Effects of $\mathrm{MnO}_{2}$ on the Electromagnetic Properties of NiCuZn Ferrites Prepared by Sol-Gel Auto-Combustion," Journal of Magnetism and Magnetic Materials, Vol. 233, No. 13, 2001, pp. 224-229. doi:10.1016/S0304-8853(01)00200-1

[8] K. O. Low and F. R. Sale, "The Development and Analysis of Property-Composition Diagrams on Gel-Derived Stoichiometric NiCuZn Ferrite," Journal of Magnetism and Magnetic Materials, Vol. 256, No. 1-3, 2003, pp. 221-226. doi:10.1016/S0304-8853(02)00482-1

[9] T. Nakamura, "Low-Temperature Sintering of Ni-Zn-Cu Ferrite and Its Permeability Spectra," Journal of Magnetism and Magnetic Materials, Vol. 16, No. 8, 1997, pp. 285-291. doi:10.1016/S0304-8853(96)00709-3

[10] S. A. Olofa, "Oscillographic Study of the Dielectric Polarization of Cu-Doped NiZn Ferrite," Journal of Magnetism and Magnetic Materials, Vol. 131, No. 1-2, 2000, pp. 103-106. doi:10.1016/0304-8853(94)90016-7

[11] C. S. Kim,W. C. Kim, S. Y. An and S.W. Lee, "Structure and Mössbauer studies of $\mathrm{Cu}$-doped $\mathrm{Ni}-\mathrm{Zn}$ ferrite,"
Journal of Magnetism and Magnetic Materials, Vol. 215216, No. 2, 2000, pp. 213-216. doi:10.1016/S0304-8853(00)00120-7

[12] H. G. Zhang, Z. Ma, J. Zhou, Z. Yue, L. Lu and Z. Gui, "Preparation and Investigation of $\left(\mathrm{Ni}_{0.15} \mathrm{Cu}_{0.25} \mathrm{Zn}_{0.60}\right)$ $\mathrm{Fe}_{1.96} \mathrm{O}_{4}$ Ferrite with Very High Initial Permeability from Self-Propagated Powders," Journal of Magnetism and Magnetic Materials, Vol. 213, No. 3, 2000, pp. 304-308. doi:10.1016/S0304-8853(99)00830-6

[13] S. R. Murthy, "Low Temperature Sintering of NiCuZn Ferrite and Its Electrical, Magnetic and Elastic Properties," Journal of Materials Science Letters, Vol. 21, No. 8, 2002, pp. 657-660. doi:10.1023/A:1015608625798

[14] M. Fujimotto, "Inner Stress Induced by $\mathrm{Cu}$ Metal Precipitation at Grain Boundaries in Low-Temperature-Fired Ni-Zn-Cu Ferrite," Journal of the American Ceramic Society, Vol. 77, No. 11, 1994, pp. 2873-2878. doi:10.1111/j.1151-2916.1994.tb04517.X

[15] S. F. Wang, Y. R. Wang, T. C. K. Yang, C. F. Chen, C. A. $\mathrm{Lu}$ and C.Y. Huang, "Densification and magnetic properties of low-fire NiCuZn ferrites," Journal of Magnetism and Magnetic Materials, Vol. 220, No. 2-3, 2000, pp. 129-138. doi:10.1016/S0304-8853(00)00491-1

[16] S. F. Wang, Y. R. Wang, T.C. K. Yang, C. F. Chen and C. A. Lu, "Effects of Processing on the Densification and Properties of Low-Fire NiCuZn Ferrites," Scripta Materialia, Vol. 43, No. 3, 2000, pp. 269-274. doi:10.1016/S1359-6462(00)00402-4

[17] T. Ochiai. J. Magn. Soc. Japan., 22 (Suppl.S1) (1998) pp.13.

[18] M. Kumagai and Y. Ikeda, "Proc of $5^{\text {th }}$ International Conference on Ferrites"., Bombay, India (1989) .

[19] N. R. Reddy, M. V. Ramana, G. Rajitha, E. Rajagopal, K.V. Sivakumar and V. R. K. Murthy, "Stress Sensitivity of Inductance in NiCuZn Ferrites," Journal of Magnetism and Magnetic Materials, Vol. 292, 2005, pp. 159-163.

[20] A. Nakano, H. Momoi and T. Nomura "Proc of $6^{\text {th }}$ International Conference on Ferrites" Kyoto: Japan Soc. of Powd and Powd. Metall., (1992) pp.1225.

[21] A. Ono, T. Muruno and N. Kaihara. Electrical Engineering in Japan, Vol. 28, 1991, pp. 5.

[22] T. Nomura and A. Namano. "Proc. of $6^{\text {th }}$ International Conference on Ferrites” Kyoto: Japan. Soc. of Powd and Powd Metall., (1992). pp.1198.

[23] K. Hirota, T. Aoyama, S. Enomoto, M. Yoshinaka and O. Yamaguchi, "Microstructures and magnetic and electric properties of low-temperature sintering Mn-Zn ferrites without and with addition of lithium borosilicate glass," Journal of Magnetism and Magnetic Materials, Vol. 205, No. 2-3, 1999, pp. 283-289. doi:10.1016/S0304-8853(99)00480-1

[24] T. Aoyama, K. Hirota and O. Yamaguchi, "Characterization and Low-Temperature Sintering of Reactive Mn-Zn Ferrite Powder," Journal of the American Ceramic Society, Vol. 79, No. 10, 1996, pp. 2792-2794. doi:10.1111/j.1151-2916.1996.tb09054.x

[25] E. Rezlscue, et al., "Effect of Copper Oxide Content on 
Intrinsic Properties of MgCuZn Ferrite," Materials Research Bulletin, Vol. 33, No. 6, 1998, pp. 915-925. doi:10.1016/S0025-5408(98)00050-6

[26] H. J. Yan, K. W. Song, S. H. Dar and C. C. Jen, "Low temperature fired NiCuZn ferrite," IEEE Transactions on Magnetics, Vol. 30, No. 6, 1994, pp. 4875-4877. doi: 10.1109/20.334251

[27] J. G. Koh and C. I. Yu. New Phys., (Korean Phys, Soc.) 247 (1984) pp.359.

[28] J. Park, J. Kim and S. Cho. J. Phys., (France) C1- 193, (1997) pp.79.

[29] J. G. Koh and K. U. Kim. New Phys., (Korean Phys, Soc) 26 (1986) pp. 540.

[30] N. Rezlescu, E. Rezlescu, P. D. Popa, L. Craus and L. Rezlescu, "Copper Ions Influence on the Physical Properties of a Magnesium-Zinc Ferrite," Journal of Magnetism and Magnetic Materials, Vol. 182, No. 1-2, 1998, pp. 199-206. doi:10.1016/S0304-8853(97)00495-2

[31] X. Qi, J. Zhou, Z. Yue, Z. Gui and L. Li, "Effect of Mn Substitution on the Magnetic Properties of MgCuZn Ferrites," Journal of Magnetism and Magnetic Materials, Vol. 251, No. 3, 2002, pp. 316-322. doi:10.1016/S0304-8853(02)00854-5

[32] N. Rezlescu, L. Sachlarie, E. Rezlescu and P. D. Popa, "Influence of $\mathrm{PbO}$ and $\mathrm{Ta}_{2} \mathrm{O}_{5}$ on Some Physical Properties of MgCuZn Ferrites," Crystal Research and Technology, Vol. 36, No. 2, 2001, pp. 157-167. doi:10.1002/1521-4079(200102)36:2<157::AID-CRAT1 57>3.0.CO;2-9

[33] L. Sachlarie, E. Rezlescu Phys Stat. Solidi., and N. Rezlescu. (a) 179 (2000) pp. R1.

[34] D. N. Bhosale, N. D. Choudari, S. R. Sawant and P. P. Bakare, "Initial Permeability Studies on High Density $\mathrm{Cu}-\mathrm{Mg}-\mathrm{Zn}$ Ferrites," Journal of Magnetism and Magnetic Materials, Vol. 173, No. 1-2, 1997, pp. 51-58. doi:10.1016/S0304-8853(97)00178-9

[35] Z. Kaczkowski, "Stress Sensitivity in Ni-Mn, Ni-Mn-Co and Ni-Mn-Co-Cu Ferrites," Journal of Magnetism and Magnetic Materials, Vol. 41, No. 1-3, 1984, pp. 338-340. doi:10.1016/0304-8853(84)90213-0

[36] I. Kanada, T. Murase and T. Nomura, "Title of This Paper (in English)," Journal of the Japan Society of Powder and Powder Metallurgy, Vol. 48, No. 2, 2001, pp. 136139. doi: $10.2497 /$ jispm. 48.136

[37] A. Bienkowski,et al., "Effects of Stress and Its Dependence on Microstructure in Mn-Zn Ferrite for Power Applications," Journal of Magnetism and Magnetic Materials, Vol. 254-255, 2003, pp. 547-549.

[38] J. A. Paulsen, A. P. Ring, C. C. H. Lo, J. E. Snyder and D. C. Jiler, "Manganese-Substituted Cobalt Ferrite Magnetostrictive Materials for Magnetic Stress Sensor Applications," Journal of Applied Physics, Vol. 97, No. 4, 2005, pp. 044502-044502-3. doi:10.1063/1.1839633

[39] M. I. Abd. El-Ati and A. Tawafik. J. Therm. Anal and Calor., 37 (1991) pp.2465.

[40] Czecnoslovak. J. Phys., 13 (1963) pp.518.

[41] B. W. Jong, "Control of Stress Sensitivity in Gadolinium
Yttrium Iron Garnets," Journal of Materials Science, Vol. 13, No. 2, 1978, pp. 459-460. doi:10.1007/BF00647796

[42] Enokidoy, Saitah, N. Sato, T. Nomura and P. Vincenzini."Advances in Science Technology, World Ceramics Congress"., Florence, ITALIE (14-19 June 1998).

[43] T. Yamaguchi and M. Shingawa, "Effect of Glass Addition and Quenching on the Relation between Inductance and External Compressive Stress in Ni-Cu-Zn Ferrite-Glass Composites," Journal of Materials Science, Vol. 30, No. 2, 1995, pp. 504-508. doi: $10.1007 / \mathrm{BF} 00354418$

[44] H. Meharabi and B. Mintz, "Title of This Paper," Materials Science and Technology, Vol. 13, No. *, 1997, pp. 997-***

[45] D. X. Yang, K. P. Kankolenski, S. Z. Hua, L. J. Swartzendruber, G. E. Hicho and H. D.Chopra, "Evaluation of Mechanical Properties of Magnetic Materials Using a Non-Destructive Method," IEEE Transactions on Magnetics, Vol. 37, No. 4, 2001, pp. 2758-2760. doi: $10.1109 / 20.951298$

[46] J. T. Vaughn, P. R. Cox, G. P. Rodrgue and G. P.Harrison, "Title of This Paper," IEEE Transactions on Microwave Theory and Techniques, Vol. 46, No. *, 1995, pp. $1017-* * * *$.

[47] J. T. Vaughn, P. R. Cox, G.P. Rodrgue and G.P. Harrison, "Title of This Paper," "Microwave Symposium Digest, IEEE MTT-5, Vol. 1, No. *, 1994, pp. 113-***.

[48] I. Y. Ikeda and M. Kumagi, "Title of This Paper (in English)," Journal of the Japan Society of Powder and Powder Metallurgy, Vol. 45, No. 1, 1998, pp. 53-57. doi: $10.2497 /$ jispm. 45.53

[49] A. Nakano, T. Suzuki and H. Momoi, "Title of This Paper (in English)," Journal of the Japan Society of Powder and Powder Metallurgy, Vol. 49, 2002, pp. 77-86. doi:10.2497/jjspm.49.77

[50] M. Kumagi and Y. Ikeda, "Title of This Paper," Proceedings of $5^{\text {th }}$ International Conference of Ferrites, Bombay, 1989, pp. 625-***.

[51] A. Nakano. I. Nakahata and T. Murase, "Title of This Paper (in English)," Journal of the Japan Society of Powder and Powder Metallurgy, Vol. 48, No. 2, 2001, pp. 131-135. doi:10.2497/jjspm.48.131

[52] T. Akoi, H. Umeda, K. Akasura and T. Musare, "Title of This Paper (in English)," Journal of the Japan Society of Powder and Powder Metallurgy, Vol. 53, No. 3, 2006, pp. 273-276. doi: $10.2497 /$ jjspm.53.273

[53] M. Kuroda, "A Phenomenological Plasticity Model Accounting for Hydrostatic Stress-Sensitivity and VertexType of Effect," Mechanics of Materials, Vol. 36, No. 3, 2004, pp. 285-297. doi:10.1016/S0167-6636(03)00023-1

[54] M. Bruonig, "Numerical Simulation of the Large ElasticPlastic Deformation Behavior of Hydrostatic Stress-Sensitive Solids," International Journal of Plasticity, Vol. 15, No. 11, 1999, pp. 1237-1264. doi:10.1016/S0749-6419(99)00042-X

[55] M. Bruonig, "Title of This Paper," International Journal of Solids and Structures, Vol. 38, No. *, 2001, pp. 
$635-* * *$.

[56] M. Bruonig, S. Berger and H. Obrecht, "Numerical Simulation of the Localization Behavior of HydrostaticStress-Sensitive Metals," International Journal of $\mathrm{Me}$ chanical Sciences, Vol. 42, No. 11, 2006, pp. 2147-2166. doi:10.1016/S0020-7403(00)00002-3

[57] T. Aoki, T. Murase and T. Nomura, "Title of This Paper (in English)," Journal of the Japan Society of Powder and Powder Metallurgy, Vol. 48, No. 2, 2001, pp. 140-144. doi: $10.2497 /$ jispm.48.140

[58] I. Nakahata, T. Murase and A. Nakano, "Title of This Paper (in English)," Journal of the Japan Society of Powder and Powder Metallurgy, Vol. 48, No. 2, 2001, pp.126-130. doi:10.2497/jjspm.48.126

[59] A. Nakano, T. Suzuki and H. Momoi, "Title of This Paper (in English)," Journal of the Japan Society of Powder and Powder Metallurgy, Vol. 49, No. 2, 2002, pp. 77-86. doi:10.2497/jispm.49.77

[60] S. Murayamna, M. Kumagi and Y. Ikeda, "Title of This Paper," Proceedings of $6^{\text {th }}$ International Conference on Ferrites, Kyoto, 1992, pp. 366-***.

[61] D. Temme, et al., "Title of This Paper," Microwave Symposium Digest, GMTT International, Vol. 71, No. *, 1971, pp. 74-**.

[62] G. Mian and O. Yamaguchi, "The Effect of Microstructure on Residual Stress-Producing and -Releasing Mechanisms in Ceramics Processing," Journal of Mechanical Sciences, Vol. 26, No. 7, 1991, pp. 1775-1780. doi:10.1007/BF00543601

[63] J. Smit and H. P. J. Wijn, "Ferrites," Philips Technical Library, Eindhoven, 1959. 